\title{
$\beta$-Adrenergic Receptors and Cyclic Adenosine Monophosphate Generation in Human Fetal Lung
}

\author{
D. J. DAVIS, B. J. DATTEL, P. L. BALLARD, AND J. M. ROBERTS
}

Cardiovascular Research Institute, Departments of Obstetrics-Gynecology and Reproductive Sciences and Pediatrics, University of California, San Francisco and Department of Pediatrics, Mount Zion Hospital and Medical Center, San Francisco, California

\begin{abstract}
We designed experiments to determine whether $\beta$-adrenergic receptors are present and functional in human fetal lung during the 2 nd trimester of gestation. To determine the presence of $\beta$ receptors, characterize their binding sites, and assess changes in receptor with gestational age, we performed radioligand binding assays with the specific, high-affinity $\beta$ antagonist, ${ }^{125} \mathrm{I}$-iodocyanopindolol, in membrane particulates from the lungs of 2nd trimester abortuses (15-23 wk). Binding of ${ }^{125} \mathrm{I}$-iodocyanopindolol was saturable and of high affinity (dissociation constant $=40 \mathrm{pM}$ ). Binding was stereoselective as determined by competition studies with $(-)$ and $(+)$ stereoisomers of propranolol. Agonist affinities (isoproterenol $>$ epinephrine $\gg$ norepinephrine) were consistent with a predominance of $\beta-2$ receptors; this predominance was confirmed by competition studies with the specific $\beta$-2 receptor antagonist ICI 118-551 (75\% $\beta-2,25 \% \beta-1)$. The concentration of $\beta$-adrenergic receptors increased with gestational age. To assess the functional coupling of the $\beta$ receptors, we tested the ability of receptor occupancy to activate adenylate cyclase. For this assay, we incubated minced human fetal lung with $\beta$ agonists and determined the amount of cAMP generated. $\beta$ Agonists stimulated cAMP generation more than 2 -fold. We conclude that $\beta$ adrenergic receptors are present and functional in human fetal lung as early as the 2 nd trimester. (Pediatr Res 21:142-147, 1986)
\end{abstract}

\section{Abbreviations}

ICYP, ${ }^{125}$ I-iodocyanopindolol

ATP, adenosine triphosphate

cAMP, cyclic adenosine monophosphate

$\operatorname{Gpp}(\mathrm{NH}) \mathrm{p}, 5^{\prime}$-guanylylimidodiphosphate

GTP, guanosine triphosphate

$\mathrm{K}_{\mathrm{p}}$, dissociation constant

There is increasing evidence for an integral role of adrenergic responses in the complex transition which the fetal lungs undergo in preparation for extrauterine life. Indirect evidence comes from clinical situations in which infants are not exposed to high levels of the adrenergic catecholamines, epinephrine and norepinephrine. For example, infants born by cesarean section without labor

Received March 26, 1986; accepted September 18, 1986.

Correspondence James M. Roberts, M.D., 1462 HSE, Box 0550, University of California, San Francisco, San Francisco, CA 94143.

Supported by NIH Grant HL30541 and HL24056. B.J.D. is a Kennedy-Dannreuther fellow of the American Foundation of Obstetricians and Gynecologists. have lower concentrations of catecholamines in amniotic fluid and cord blood than do those delivered vaginally or by cesarean section after labor (1). In association with these lower catecholamine levels, infants born by cesarean section without labor have a higher incidence of breathing difficulties (2), less mature biochemical indices of lung maturity $(3,4)$, and lower tidal volumes and lung compliance (1) than do other infants. In contrast, infants born to mothers who received $\beta$-adrenergic agonists immediately before delivery are reported to have a lower incidence of hyaline membrane disease (5).

In other species, there is substantial experimental evidence that $\beta$-adrenergic responses are involved in fetal lung maturation (6). Administration of $\beta$-adrenergic agonists to fetal sheep and rabbits significantly decreases lung water content $(7,8)$, increases surfactant release $(9,10)$, and increases lung stability $(11,12)$. In fetal rabbits, administration of an irreversible $\beta$-adrenergic blocker (13) or prevention of epinephrine synthesis (14) decreases the surfactant release that accompanies labor. In addition, other studies have shown both an increase in $\beta$-adrenergic receptor concentration $(15,16)$ and an increased sensitivity to $\beta$-adrenergic agonists $(7,8)$ with advancing gestational age.

In the human, direct evidence for the role of $\beta$-adrenergic responses in fetal lung maturation is lacking. Therefore, we designed a study to determine whether $\beta$-adrenergic receptors are present and functionally coupled in human fetal lung during the 2 nd trimester of gestation. To assess the presence of $\beta$-adrenergic receptors, characterize their binding sites, and identify changes in receptor concentration with gestational age, we performed radioligand binding studies with the specific, high-affinity $\beta$ adrenergic antagonist, ICYP in human fetal lung at 15-23 wk of gestation. To demonstrate function, we assessed receptor activation of adenylate cyclase, the enzyme responsible for the conversion of ATP to CAMP, an important "second messenger" for many biological functions. For this assessment, we studied cAMP generation in 2 nd trimester fetal lung tissue in response to three $\beta$-adrenergic agonists: isoproterenol, prostaglandin $\mathrm{E} 1$, and forskolin. Our findings indicate the presence of $\beta$-adrenergic receptors, primarily of the $\beta-2$ subtype, in human fetal lung which increase with advancing gestation and are coupled to cAMP generation.

\section{MATERIALS AND METHODS}

Tissue. Human fetal lung tissue obtained from abortuses after elective terminations of pregnancy in the 2 nd trimester was used in these studies. Upon receipt, most of the specimens were immediately frozen and stored at $-70^{\circ} \mathrm{C}$ until preparation of membrane particulates. Some specimens were processed into membrane particulates immediately to ascertain that the tissue was not damaged by the storage procedure. Since no differences in receptor concentration or agonist affinities were found between fresh and frozen tissue, subsequent binding assays were 
performed on frozen tissue. Studies of cAMP generation were conducted on freshly obtained lung tissue from 2 nd trimester abortuses.

Materials. ICYP (2200 Ci/mmol) and cAMP (31.5-33.5 Ci/ $\mathrm{mmol}$ ) were purchased from New England Nuclear Corporation (Boston, MA). (-)Isoproterenol bitartrate, (-)epinephrine bitartrate, (-)norepinephrine hydrochloride, prostaglandin $E 1$, cAMP-dependent protein kinase, Gpp(NH)p, 3-isobutyl-1-methylxanthine, and other chemicals were purchased from Sigma Chemical Company (St. Louis, MO). Forskolin was purchased from Behring Diagnostics (La Jolla, CA).

Membrane preparation. Partially purified membrane particulates of 2 nd trimester human fetal lung were prepared by differential centrifugation in the following manner. First, fresh lung tissue or thawed frozen lung tissue was dissected free of major blood vessels or airways and then weighed. Each specimen was chopped and placed in 10 volumes of ice-cold buffer $(50 \mathrm{mM}$ Tris and $4 \mathrm{mM}$ EDTA, pH 7.4) and then homogenized by either a Virtis homogenizer (Virtis Co., Gardiner, NY) or a Tekmar Tissumizer (Tekmar, Cincinnati, $\mathrm{OH}$ ). The homogenate was filtered through two layers of cheesecloth and then centrifuged at $1200 \times g$ for $15 \mathrm{~min}$. The pellet was discarded and the supernatant was centrifuged at $29,000 \times g$ for $15 \mathrm{~min}$. The supernatant was then discarded and the pellet containing the membrane particulate was resuspended in ice-cold buffer ( 50 $\mathrm{mM}$ Tris and $4 \mathrm{mM}$ magnesium chloride, $\mathrm{pH}$ 7.4) by a Dounce homogenizer. The membrane particulate was washed by three cycles of high speed centrifugation and resuspension in ice-cold buffer. For the third resuspension, $1 \mathrm{ml}$ of the Tris and magnesium chloride buffer per $3 \mathrm{~g}$ of initial tissue was used. Protein concentration was determined using the Bradford method (17) with bovine serum albumin as the standard. The partially purified crude membrane particulates were frozen in liquid nitrogen and stored at $-70^{\circ} \mathrm{C}$ until assayed.

Binding studies. To identify the $\beta$-adrenergic receptor and to determine receptor concentrations in lung particulates of different gestational ages, binding assays for saturation analysis were performed in the following manner. The lung particulates (approximately $60 \mu \mathrm{g}$ protein) were incubated at $30^{\circ} \mathrm{C}$ for $90 \mathrm{~min}$ in a $0.25 \mathrm{ml}$ volume containing $50 \mathrm{mM}$ Tris and $4 \mathrm{mM}$ magnesium chloride buffer ( $\mathrm{pH} 7.4$ ), $1 \mathrm{mM}$ ascorbic acid, and 5-500 pM ICYP, with or without $100 \mu \mathrm{M}$ isoproterenol. At the end of the incubation $5 \mathrm{ml}$ of ice-cold buffer was added and the samples were filtered through Whatman GF/C glass fiber filters to separate free and bound ICYP. After three washes, the filters were dried and counted in a Packard auto- $\gamma$ spectrometer. Nonspecific binding was determined by incubation of membrane protein with ICYP in the presence of $100 \mu \mathrm{M}$ isoproterenol and was always less than $20 \%$ of total binding at an ICYP concentration near to the $K_{D}$. When this nonspecific binding was subtracted from total binding to yield specific binding, the values for specific binding were not different from those found when specific binding was determined as highest affinity binding by computer curve-fitting (18); therefore, in order to conserve tissue and increase accuracy, specific binding was determined by computer curve-fitting.

Kinetic analysis was performed to validate the $\mathrm{K}_{\mathrm{D}}$ determined by saturation analysis. In these experiments, the membrane particulate (approximately $60 \mu \mathrm{g}$ of membrane protein) was incubated at $30^{\circ} \mathrm{C}$ in a $0.25-\mathrm{ml}$ volume containing $50 \mathrm{mM}$ Tris and $4 \mathrm{mM}$ magnesium chloride ( $\mathrm{pH} 7.4), 1 \mathrm{mM}$ ascorbic acid, and $50 \mathrm{pM}$ ICYP. The time course to saturation was verified by stopping the incubations at specified times by addition of icecold buffer, and filtering and washing the samples to separate bound from free ligand as described above. At $90 \mathrm{~min}$, the samples for the kinetic analysis were diluted 100 -fold by the addition of $10^{-4} \mathrm{M}$ isoproterenol in Tris and magnesium chloride buffer at $30^{\circ} \mathrm{C}$. These incubations were stopped at specified times by addition of ice-cold buffer, filtering, and washing. To verify that the decreased binding observed was the result of reversal rather than degradation of the receptor-ligand complex, some samples were incubated unperturbed for specified times from 90 to $180 \mathrm{~min}$, at which time the incubations were stopped as described above.

To determine the binding characteristics of the receptor, competition experiments were performed. Stereoselectivity was assessed by assays in which ICYP competed for the binding sites of the receptor with (-) and (+) stereoisomers of propranolol. Agonist affinities were assessed by assays in which ICYP competed with isoproterenol, epinephrine, and norepinephrine. Receptor subtypes were determined from these agonist affinities (18) as well as from assays in which ICYP competed for the binding sites with ICI 118,551 , a specific $\beta-2$ antagonist. Finally, sensitivity of the binding interaction to guanyl nucleotides was determined from assays in which ICYP competed for the binding sites with isoproterenol in the presence and absence of $\mathrm{Gpp}(\mathrm{NH}) \mathrm{p}$, a nonhydrolyzable analogue of GTP. These competition experiments were all performed in the following manner. Lung particulates (approximately $40 \mu \mathrm{g}$ protein) were incubated at $30^{\circ} \mathrm{C}$ for $90 \mathrm{~min}$ in a $0.25-\mathrm{ml}$ volume containing $50 \mathrm{mM}$ Tris and $4 \mathrm{mM}$ magnesium chloride buffer ( $\mathrm{pH} 7.4), 1 \mathrm{mM}$ ascorbic acid, $50 \mathrm{pM}$ ICYP, and $0.1 \mathrm{nM}-0.01 \mu \mathrm{M}$ of the $\beta$-adrenergic agonist or antagonist that was being studied. The washing and filtration steps were as described for the binding assays.

cAMP generation. To investigate the function of the $\beta$-adrenergic receptor in human fetal lung, the ability of $\beta$-adrenergic agonists to stimulate cAMP generation was assessed as follows. cAMP content was determined by incubating duplicate samples of $50 \mathrm{mg}$ of fresh human fetal lung tissue in a $0.25-\mathrm{ml}$ volume of $5 \mathrm{mM}$ Tris and $0.9 \%$ sodium chloride, $1 \mathrm{mM}$ 3-isobutyl-1methylxanthine (a phosphodiesterase inhibitor) and $0.1 \mathrm{mM}$ ascorbic acid. Basal cAMP generation was determined by incubating duplicate samples of approximately $50 \mathrm{mg}$ of fresh human fetal lung tissue in an identical buffer solution for $10 \mathrm{~min}$ at $37^{\circ}$ C. Agonist-stimulated cAMP generation was determined in the same manner as basal cAMP generation except that the buffer solution contained different concentrations of one or more $\beta$ agonists [isoproterenol $(10 \mathrm{nM}-100 \mu \mathrm{M})$, prostaglandin E1 (1$100 \mu \mathrm{M})$, or forskolin $(30 \mu \mathrm{M})]$. For all three determinations, the reaction was stopped by adding an equal volume of $10 \%$ trichloroacetic acid. After homogenization and centrifugation, a 5:1 ether extraction was performed a total of three times on each sample. Any remaining ether was evaporated in a $70^{\circ} \mathrm{C}$ water bath for $20 \mathrm{~min}$.

cAMP binding was then assessed by a modification of the assay described by Gilman (20). For this assay, a 0.35 -ml volume containing the diluted tissue extract, $50 \mathrm{mM}$ sodium acetate $(\mathrm{pH}$ 4), $10 \mathrm{nM}^{3} \mathrm{H}$-cAMP, and $12.5 \mu \mathrm{g} \mathrm{3}^{\prime}, 5^{\prime}$-cAMP-dependent protein kinase was incubated at $4^{\circ} \mathrm{C}$ for $60 \mathrm{~min}$. A standard curve was obtained by incubating the blank buffer solution from the generation step with $0-80 \mathrm{pmol}$ cAMP in $50 \mathrm{mM}$ sodium acetate (pH 4), $10 \mathrm{nM}{ }^{3} \mathrm{H}$-cAMP, and $12.5 \mu \mathrm{g}$ protein kinase. The samples were washed and filtered over Gelman metricel membrane filters using $4 \mathrm{ml}$ of $20 \mathrm{mM}$ potassium phosphate (monobasic) and $1 \mathrm{mM}$ magnesium sulfate buffer ( $\mathrm{pH} 4)$ at $4^{\circ} \mathrm{C}$ a total of four times. The filters were dried and then dissolved in $3.8 \mathrm{ml}$ Hydrofluor and counted in a Packard Tricarb liquid scintillation counter.

Calculations. The amount of ligand bound to the filters was analyzed as a function of free ligand (as calculated from the known initial counts) by an iterative, nonlinear curve-fitting program prepared for a Hewlett-Packard 9825A desktop computer. The program repeatedly analyzes the data with different parameters until the set of parameters resulting in minimal weighted residual variance is found. This curve-fitting analysis is able to determine the parameters which best fit the mathematical model for that particular line or curve, as well as determine the model which best describes the data (18).

Parameters from binding assays for saturation analysis $\left(K_{D}\right.$ and receptor concentration) were determined by this computer- 
ized analysis. These parameters were then used to array data as described by Scatchard (21).

Data from competition experiments was analyzed by an iterative nonlinear curve fitting program which examines binding in the presence of the competitor as a function of that concentration of competitor. Residual variance in the simplest model (one class of sites) was compared with that of models of increasing complexity (greater than one class of sites). The model is accepted when models of increasing complexity did not result in a statistically significant reduction in the residual variance (18). This analysis determines the $\mathrm{I}_{50}(\mathrm{~s})$ (the concentration of competitor reducing binding to particular sites by $50 \%$ ) and the percentage of binding sites with which the competitor competes with this $I_{50}$. Since experiments were conducted at concentrations of binding sites such that total radioligand was essentially constant we used the relationship described by Cheng and Prusoff $(22) K_{I}=$ $\mathrm{I}_{50} /\left(1+\mathrm{L}_{\mathrm{F}} / \mathrm{K}_{\mathrm{D}}\right)$ to determine the $\mathrm{K}_{\mathrm{I}}(\mathrm{s})$ for competitors. In this equation $\mathrm{L}_{F}$ is the concentration of radioligand and $\mathrm{K}_{D}$ its $\mathrm{K}_{\mathrm{D}}$ determined in independent experiments.

Data for CAMP generation were derived from a linear regression using standard curves obtained from known amounts of nonradioactive cAMP added to the buffer or to the tissue extract. Differences between standard curves obtained with these diluents were completely explained by the cAMP content of the extract.

\section{RESULTS}

Characteristics of the $\beta$-adrenergic receptor. Binding of the specific $\beta$-adrenergic antagonist ICYP in membrane particulates of human fetal lung from the 2 nd trimester of gestation demonstrated the characteristics of a radioligand binding to a $\beta$-adrenergic receptor. The binding by ICYP was saturable and of high affinity (Fig. 1). The $\mathrm{K}_{\mathrm{D}}$ for all samples assayed was approximately $0.040 \mathrm{nM}$ (range 0.027 to $0.053 \mathrm{nM}$ ) and did not vary with gestational age. The dissociation constant was also determined in kinetic experiments. The $\mathrm{k}_{\text {on }}$ was $9.9 \times 10^{7} \mathrm{M}^{-1}$. The reversal was first order with a $\mathrm{k}_{\text {orf }}$ of $3.75 \times 10^{-3} \mathrm{~min}^{-1}$. The $\mathrm{K}_{\mathrm{D}}$

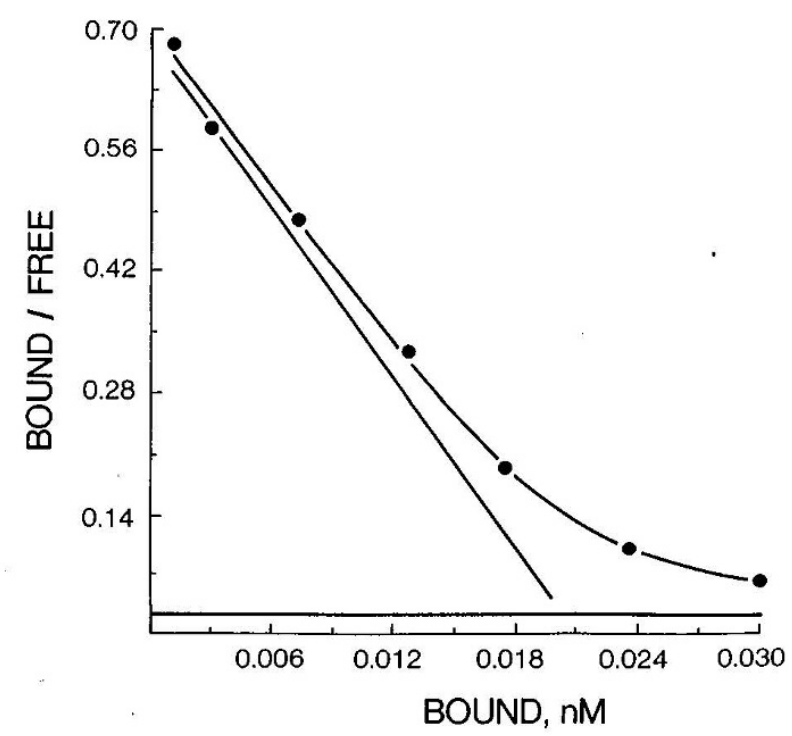

Fig. 1. Saturation analysis of total binding of ICYP to the $\beta$-adrenergic receptor in a 22.2-wk human fetal lung. Approximately $60 \mu \mathrm{g} \mathrm{mem-}$ brane protein was incubated with 5-500 pM ICYP for $90 \mathrm{~min}$ at $30^{\circ} \mathrm{C}$. Bound and free ligand were separated by filtration. Data are arrayed as a Scatchard plot. The dark circles and curved line through them represent the actual data points and the computer-generated line of best fit. This line can be resolved into two components: the line parallel to the $\mathrm{x}$ axis which represents nonspecific binding, and the straight line to the left of the data points which represents the single class of saturable, high-affinity binding sites. calculated from these values was $38 \mathrm{pM}$ in excellent agreement with the equilibrium determination.

The binding was stereoselective as demonstrated by (-) and $(+)$ stereoisomers of propranolol competing for ICYP binding sites. The biologically active $(-)$ stereoisomer of propranolol had a much lower inhibition constant $\left(\mathrm{K}_{\mathrm{I}}=3 \mathrm{nM}\right)$ than did the nonbiologically active $(+)$ propranolol $\left(\mathrm{K}_{\mathrm{I}}=39 \mathrm{nM}\right)$ (Fig. 2$)$.

Agonist affinities (isoproterenol $>$ epinephrine $\gg$ norepinephrine), determined by assays of these $\beta$ agonists competing for ICYP binding sites in the membrane particulates, were consistent with a predominance of $\beta-2$ receptors (Fig. 3). All three agonists showed complex binding isotherms best fitted by two binding sites, one high affinity and one low affinity: isoproterenol, $\mathrm{K}_{\mathrm{H}}=$

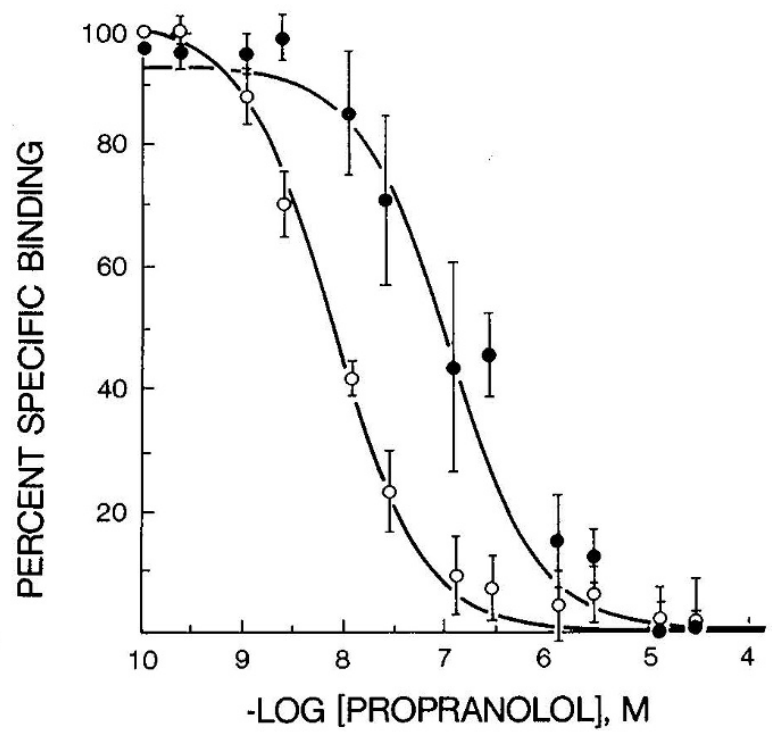

Fig. 2. Binding curves for ICYP competing with $(-)(O)$ and $(+)(\bullet)$ propranolol. Approximately $40 \mu \mathrm{g}$ of membrane protein was incubated with $50 \mathrm{pM}$ ICYP and $0.1 \mathrm{nM}-0.1 \mu \mathrm{M}$ propranolol for $90 \mathrm{~min}$ at $30^{\circ} \mathrm{C}$. Bound and free ligand were separated by filtration. Data are expressed as the mean and SEM of duplicate measurements and three tissue samples from different lungs.

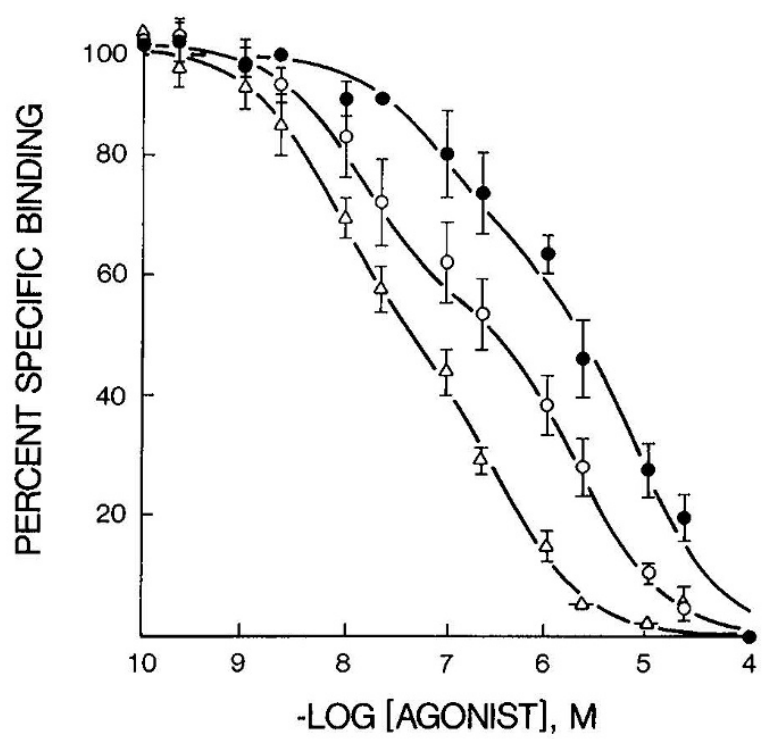

Fig. 3. Binding curves for ICYP competing with adrenergic agonists: $\triangle$ isoproterenol, $O$ epinephrine, norepinephrine. Methods as in Figure 2. Data are expressed as the mean and SEM of duplicate measurements of the tissue samples from different lungs ( $n=3$ for isoproterenol and norepinephrine, $n=4$ for epinephrine). Error bars are not shown when they are smaller than data symbols. 
$3.5 \pm 1 \mathrm{nM}, 500 \pm 7 \%, \mathrm{~K}_{\mathrm{L}}=173 \pm 50 \mathrm{nM}, 57 \pm 7 \%(n=3)$; epinephrine, $\mathrm{K}_{\mathrm{H}}=6 \pm 3 \mathrm{nM}, 430 \pm 6 \%, \mathrm{~K}_{\mathrm{L}}=904 \pm 180 \mathrm{nM}$, $570 \pm 6 \%(n=4)$; norepinephrine, $\mathrm{K}_{\mathrm{H}}=41 \pm 2 \mathrm{nM}, 33 \%, \mathrm{~K}_{\mathrm{L}}$ $=3100 \pm 700 \mathrm{nM}, 67 \pm 3 \%(n=3)$.

Binding assays of the specific $\beta$-2 receptor antagonist, ICI 118,551 , competing for ICYP binding sites confirmed this predominance of $\beta-2$ receptors. Approximately $75 \%$ of the $\beta$-adrenergic receptors in the membrane particulates of human fetal lung were $\beta-2$ and $25 \%$ were $\beta-1$ (Fig. 4 ). Preliminary studies on membrane particulates prepared using $50 \mathrm{mM}$ Tris and $4 \mathrm{mM}$ magnesium chloride as the initial buffer rather than $50 \mathrm{mM}$ Tris and $4 \mathrm{mM}$ EDTA failed to demonstrate a predominance of $\beta-2$ receptors by competition studies with either adrenergic agonists or antagonists (data not shown).

The $\beta$-adrenergic receptor binding site was sensitive to guanyl nucleotides as demonstrated by binding assays in which isoproterenol competed for ICYP binding sites in the presence and absence of $\mathrm{Gpp}(\mathrm{NH}) \mathrm{p}$ (Fig. 5). In the absence of $\mathrm{Gpp}(\mathrm{NH}) \mathrm{p}$, the isoproterenol binding isotherm was complex, best fitted by one high affinity $\left(\mathrm{K}_{\mathrm{H}}=2.7 \mathrm{nM}, 38 \%\right)$ and one low affinity $\left(\mathrm{K}_{\mathrm{L}}=89\right.$ $\mathrm{nM}, 62 \%$ ) binding site. However, in the presence of $\mathrm{Gpp}(\mathrm{NH}) \mathrm{p}$, the isoproterenol binding shifted to a single low affinity site $\left(\mathrm{K}_{\mathbf{I}}\right.$ $=134 \mathrm{nM}, 100 \%$ ).

Changes in receptor concentration with gestational age. The receptor concentration in membrane particulates of human fetal lung increased linearly with gestational age, ranging from 23 $\mathrm{fmol} / \mathrm{mg}$ at $15 \mathrm{wk}$ of gestation to $110 \mathrm{fmol} / \mathrm{mg}$ at $23 \mathrm{wk}$ of gestation (Fig. 6). In keeping with this linear increase, the receptor concentration in a lung sample from a later gestation, a 39-wk stillborn infant, was $223 \mathrm{fmol} / \mathrm{mg}$.

cAMP generation. CAMP was generated in the minces of fresh lung tissue even in the absence of $\beta$-adrenergic agonists; cAMP content prior to incubation was $2.21 \pm 0.94 \mathrm{pmol} / \mathrm{mg}$ wet weight, whereas the concentration of cAMP following $10 \mathrm{~min}$ of incubation in the absence of $\beta$-adrenergic agonists (basal cAMP) was $10.35 \pm 1.50 \mathrm{pmol} / \mathrm{mg}$ wet weight. However, isoproterenol further stimulated cAMP generation in the lung tissue in a dosedependent manner (Fig. 7) with the maximal effect (a greater than 2-fold increase) at approximately $10^{-6} \mathrm{M}$ isoproterenol; as in other human tissues, the half-maximal effect occurred at approximately $10^{-7} \mathrm{M}$ isoproterenol.

Prostaglandin E1 appeared to be a less potent stimulator of

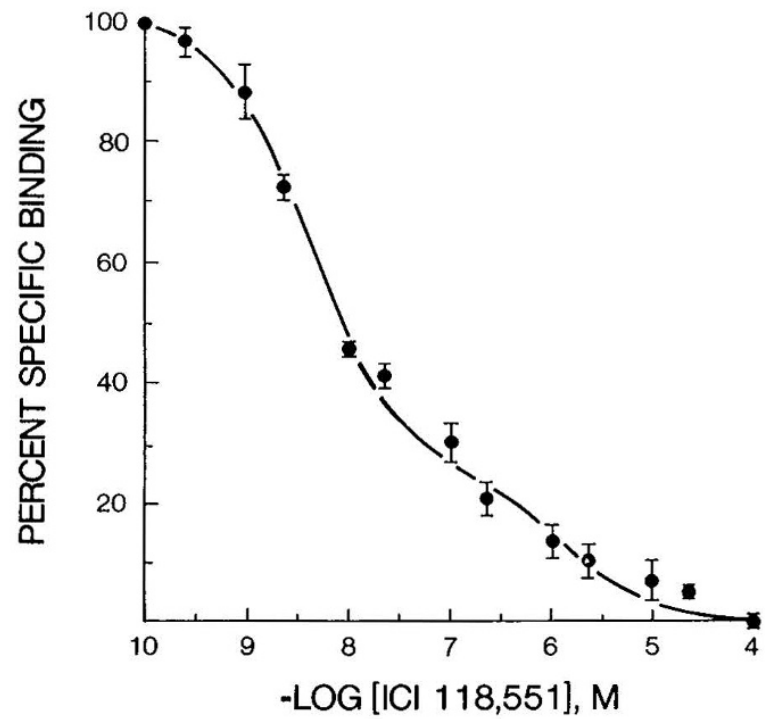

Fig. 4. Binding curve for ICYP competing with ICI 118,551 , a specific $\beta-2$ antagonist. Methods as in Figure 2. Data are expressed as the mean and SEM for duplicate measurements of three tissue samples from different lungs. Parameters determining this curve were $K_{H} 2.1 \pm 0.4$ $\mathrm{nM}, \mathrm{R}_{\mathrm{H}} / \mathrm{R}_{\mathrm{T}} 75 \pm 14 \%, \mathrm{~K}_{\mathrm{L}}=640 \pm 180 \mathrm{nM}$.

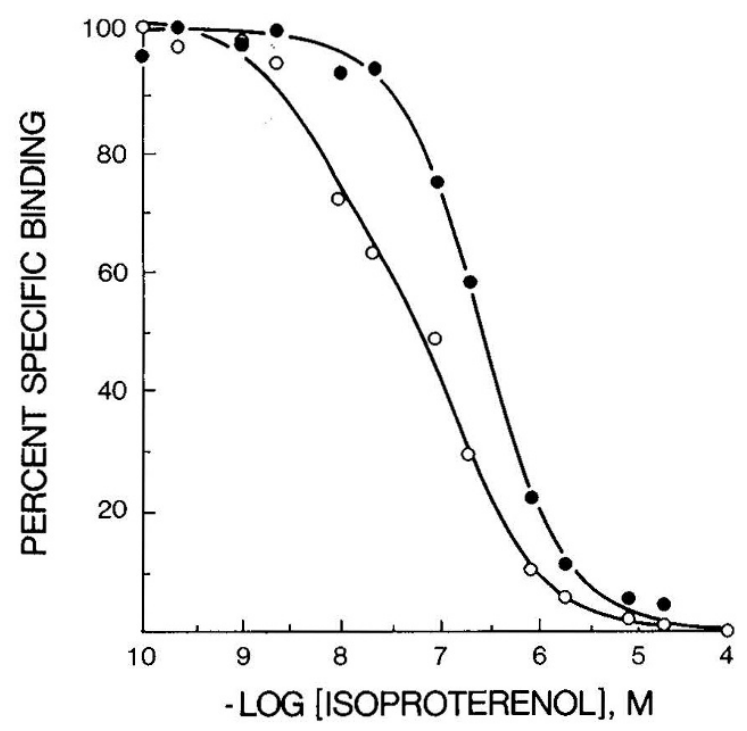

Fig. 5. Binding curves for ICYP competing with isoproterenol in the absence $(\mathrm{O})$ and in the presence $(\bullet)$ of $\mathrm{Gpp}(\mathrm{NH}) \mathrm{p}$. Methods as in Figure 2. Data are the mean of triplicate determinations in a single experiment.

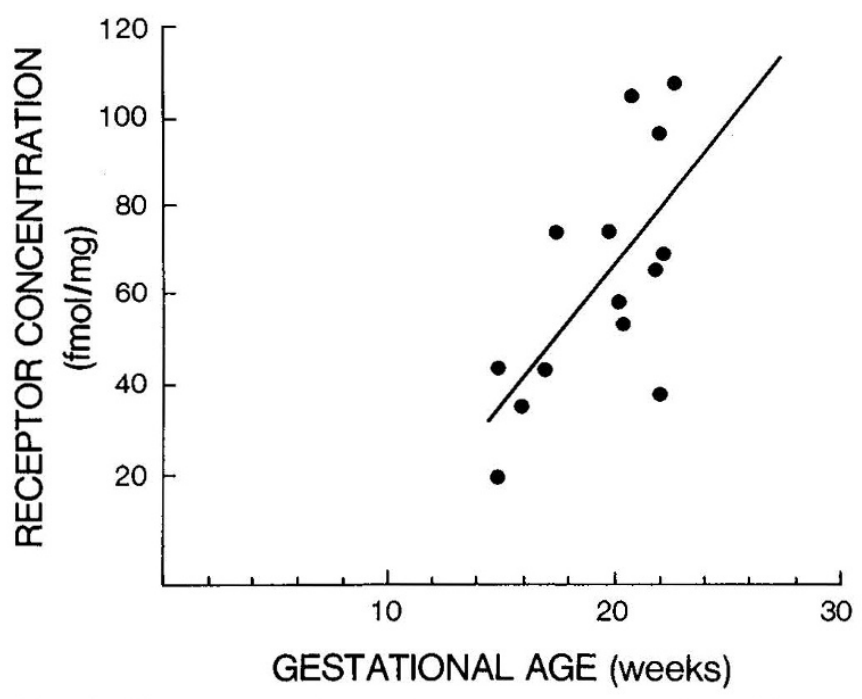

Fig. 6. Changes in $\beta$-adrenergic receptor concentration with gestational age. Receptor concentration was determined by binding assays of membrane particulate incubated with $5-500$ pM ICYP. Bound ligand was analyzed as a function of free ligand; $r=0.708, p<0.005$.

cAMP generation: it caused only a slight increase in cAMP at a concentration of $10^{-6} \mathrm{M}$ (basal cAMP $10.35 \pm 1.50 \mathrm{pmol} / \mathrm{mg}$ wet weight, prostaglandin-stimulated cAMP $15.15 \pm 2.27 \mathrm{pmol} /$ mg wet weight, $n=3$ ), although in one experiment $10^{-4} \mathrm{M}$ prostaglandin did cause a greater than 2 -fold rise in cAMP generation.

Forskolin $(30 \mu \mathrm{M})$, a potent activator of adenylate cyclase, caused a 4-fold increase in cAMP generation in each of two experiments (basal cAMP 11.14 and $12.47 \mathrm{pmol} / \mathrm{g}$ wet respectively, forskolin-stimulated cAMP 42.25 and $54.16 \mathrm{pmol} / \mathrm{g}$ wet weight, respectively). Both forskolin plus isoproterenol and forskolin plus prostaglandin E1 had supraadditive effects of similar magnitude on CAMP generation.

The ability of agonists to stimulate cAMP generation was not dependent on gestational age in the limited age range studied.

\section{DISCUSSION}

In the present study, we have demonstrated that $\beta$-adrenergic receptors are present and functional in human fetal lung as early 


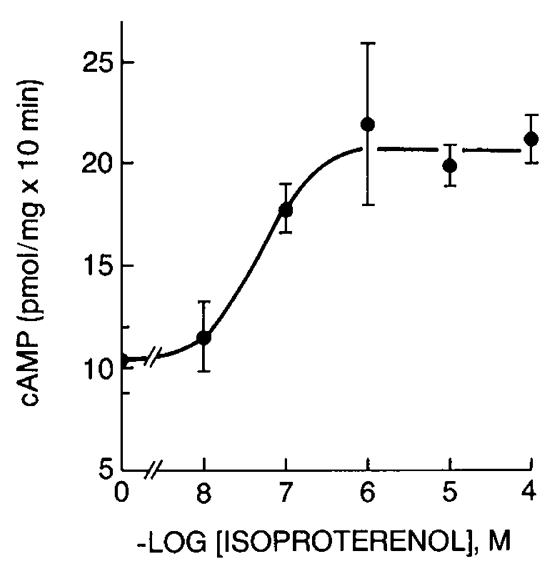

Fig. 7. Dose-response curve for isoproterenol stimulation of cAMP generation in human fetal lung tissue. Approximately $50 \mathrm{mg}$ of fresh tissue was incubated with isoproterenol $(0.1 \mathrm{nM}-1 \mu \mathrm{M})$ in the presence of a phosphodiesterase inhibitor, 3-isobutyl-1-methylxanthine (1 mM) for $10 \mathrm{~min}$ at $37^{\circ} \mathrm{C}$. The reaction was stopped with trichloroacetic acid. After centrifugation, an ether extraction was performed. The resultant "tissue extract" was incubated with ${ }^{3} \mathrm{H}$-cAMP and $3^{\prime}, 5^{\prime}$-cAMP-dependent protein kinase for $60 \mathrm{~min}$ at $4^{\circ} \mathrm{C}$. Bound and free ligand were separated by filtration. Data are expressed as the mean and SEM for duplicate measurements of tissue samples from three lungs from fetuses of $19.6-25$ wk.

as the $2 \mathrm{nd}$ trimester of gestation. The presence of $\beta$ receptors was indicated by radioligand binding by the specific, high-affinity $\beta$ antagonist ICYP, which showed that the binding site of the $\beta$ adrenergic receptor is saturable, of high affinity, and stereoselective. Furthermore, using both agonist affinities and data from competition studies with the specific $\beta$-2 antagonist, ICI 1 18,551, we have shown that the predominant receptor in 2 nd trimester human fetal lung is the $\beta-2$ subtype, as it is in human adult lung (23). The failure to demonstrate $\beta-2$ receptors in preliminary studies when EDTA was not present in the initial buffer during preparation of membrane particulates is consistent with findings in other species in which $\beta$-adrenergic receptors in lung are very sensitive to metal-dependent proteolysis (24).

We have also demonstrated that the concentration of $\beta$-adrenergic receptors in human fetal lung increases with advancing gestational age. However, the receptor concentration throughout the 2 nd trimester $(23-110 \mathrm{fmol} / \mathrm{mg}$ of membrane protein) remains significantly lower than that found in adult lung (470 $\mathrm{fmol} / \mathrm{mg}$ ) (23). In contrast, Falkay et al. (26) failed to show an increase in the concentration of $\beta$-adrenergic receptors with advancing gestational age in human fetal lung from $8-18 \mathrm{wk}$ of gestation by radioligand binding assays with ${ }^{3} \mathrm{H}$-dihydroalprenolol.

In characterizing the $\beta$-adrenergic receptor, we have also shown that $\beta$-adrenergic interactions in human fetal lung are sensitive to guanyl nucleotides. In the present study the competition of the $\beta$-adrenergic agonist, isoproterenol, for the ICYP binding sites was similar to that in adult tissues. That is, in the absence of guanyl nucleotide, the isoproterenol binding isotherm is complex and best described by one high-affinity and one low-affinity binding site. However, in the presence of guanyl nucleotide, the binding isotherm reverted to a single low-affinity site.

The finding of guanyl-nucleotide-sensitive high-affinity binding indicates that the fetal $\beta$ receptor is capable of interaction with the guanyl-nucleotide-sensitive coupling protein (Gs) when occupied by agonist (27). This sensitivity of the binding interaction to guanyl nucleotides may have important implications for the function of the $\beta$-adrenergic receptor (28).

Evidence that the $\beta$-adrenergic receptor response cascade is functional in human fetal lung during the 2nd trimester of gestation comes from our studies of agonist-stimulated cAMP generation. We have shown that isoproterenol stimulates cAMP generation in human fetal lung tissue through occupancy of the receptor, indicating functional linkage of the $\beta$-adrenergic receptor through Gs to adenylate cyclase. In other tissues, formation of cAMP within cells activates intracellular cAMP-dependent protein kinase, which results in phosphorylation and activation of specific proteins within the cell. We postulate that in the human fetal lung, the cAMP similarly acts as a second messenger and promotes cell activity which ultimately leads to lung water resorption and surfactant release and perhaps to surfactant production. Support for this postulate comes from studies which have shown that phosphatidylcholine is released in response to cAMP analogues as well as in response to $\beta$ agonists (29-31).

Prostaglandin E1, which also activates adenylate cyclase through receptor occupancy, appeared to be a less potent stimulator of cAMP generation in the human fetal lung than isoproterenol was in this study. However, comparison of CAMP content and basal cAMP generation shows that cAMP accumulated during incubation in the absence of added agonist, suggesting that some effector, possibly a prostaglandin, was present and stimulatory. This might well have blunted the effect of added prostaglandin $\mathrm{E} 1$.

Forskolin, a potent direct activator of adenylate cyclase, caused a large increase in cAMP generation when administered alone and had a supraadditive effect when given with either isoproterenol or prostaglandin E1. Thus, it appears that forskolin promotes the interaction between the guanyl nucleotide regulatory protein and the catalytic component of the adenylate cyclase system, which in intact tissues results in a supraadditive effect of agonist and forskolin.

Our findings of the presence of $\beta$-adrenergic receptors and of $\beta$ agonist stimulation of cAMP generation indicate the feasibility of studying the maturation and differentiation of the $\beta$-adrenergic receptor response cascade in human fetal lung. The modulation of this cascade by influences such as glucocorticoids and thyroid hormone is also of great interest in view of the known effects of hormonal manipulation on the surfactant system in human lung as well as in lung of other species (32) and on the development of $\beta$-adrenergic receptors in lung of other species (33-35).

In conclusion, our study shows that $\beta$-adrenergic receptors are present in human fetal lung as early as the 2 nd trimester and that their concentration increases with gestational age. This study also shows that receptor occupancy by agonist promotes cAMP generation within the cells, indicating functional linkage of the receptor to adenylate cyclase. These findings support a potential role for $\beta$-adrenergic responses in the adaptation of the human fetal lung to extrauterine life.

Acknowledgments. (+) and (-) propranolol were gifts from Ayerst Laboratories Incorporated, New York, NY and ICI 118,551 was a gift from Imperial Chemical Industries, Cheshire, England.

\section{REFERENCES}

1. Faxelius G, Hagnevik K, Lagercrantz H, Lundell B, Irestedt L 1983 Catecholamine surge and lung function after delivery. Arch Dis Child 58:262-266

2. Fedrick J, Butler NR 1972 Hyaline-membrane disease. Lancet 2:768-769

3. Whittle MJ, Hill CM, Harkes A 1977 Effect of labor on the lecithin/sphingomyelin ratio in serial samples of amniotic fluid. Br J Obstet Gynaecol 84:500 503

4. Callen P, Goldsworthy S, Graves L, Harvey D, Mellows H, Parkinson C 1979 Mode of delivery and the lecithin/sphingomyelin ratio. Br J Obstet Gynaecol 86:965-968

5. Bergman B, Hedner T 1978 Antepartum administration of terbutaline and the incidence of hyaline membrane disease in preterm infants. Acta Obstet Gynecol Scand 57:217-221

6. Roberts JM, Musci TJ 1986 Alveolar beta adrenoreceptors: modulation and role in perinatal adaptation. In: Gluckman P, Johnson B (eds) The Perinata Development of the Respiratory System. Perinatology Press, Ithaca, NY, pp 135-159

7. Lawson EE, Brown ER, Torday JS, Mandansky DL, Taeusch HW 1978 The effect of epinephrine on tracheal fluid flow and surfactant efflux in fetal sheep. Am Rev Respir Dis 118:1023-1026 
8. Brown MJ, Olver RE, Ramsden CA, Strang LB, Walters DV 1983 Effects of adrenaline and of spontaneous labour on the secretion and absorption of lung liquid in the fetal lamb. J Physiol 344:137-152

9. Enhorning G, Chamberlain D, Contreras C, Burgoyne R, Robertson B 1977 Isoxsuprine-induced release of pulmonary surfactant in the rabbit fetus. Am J Obstet Gynecol 129:197-202

10. Ekelund L, Burgoyne K, Enhorning G 1983 Pulmonary surfactant release in fetal rabbits: immediate and delayed response to terbutaline. Am $\mathrm{J}$ Obstet Gynecol 147:437-443

11. Wyszogrodski I, Taeusch HW, Avery ME 1974 Isoxsuprine-induced alterations of pulmonary pressure-volume relationships in premature rabbits. Am $\mathbf{J}$ Obstet Gynecol 119:1107-1111

12. Lipshitz J, Broyles K. Hessler JR, Whybrew WD, Ahokas RA, Anderson GD 1981 Effects of hexoprenaline on the lecithin/sphingomyelin ratio and pressure-volume relationships in fetal rabbits. Am J Obstet Gynecol 139:726734

13. McDonald JV Jr, Gonzales LK, Ballard PL, Pitha J, Roberts JM 1986 Endogenous catecholamines stimulate surfactant release but do not reduce lung water. J Appl Physiol 60:1727-1733

14. Padbury JF, Jacobs HC, Lam RW, Conaway D, Jobe AH, Fisher DA 1984 Adrenal epinephrine and the regulation of pulmonary surfactant release in neonatal rabbits. Exp Lung Res 7:177-184

15. Giannopoulos $G 1980$ Identification and ontogeny of beta-adrenergic receptors in fetal rabbit lung. Biochem Biophys Res Commun 95:388-394

16. Whitsetı JA, Machulskis A, Noguchi A, Burdsall JA 1982 Ontogeny of alpha1 and beta-adrenergic receptors in rat lung. Life Sci 30:139-145

17. Bradford MM $1976 \mathrm{~A}$ rapid and sensitive method for the quantitation of microgram quantities of protein utilizing the principle of protein-dye binding. Anal Biochem 72:248-254

18. Roberts JM 1986 Techniques for the direct examination adrenergic receptors in developmental studies. In: PW Nathanielsz (ed) Animal Models in Fetal Medicine. Perinatology Press, Ithaca, NY, pp 187-269

19. Lands AM, Arnold A, McAuliff JP, Luduena FP, Brown TG 1967 Differentiation of receptor systems activated by sympathomimetic amines. Nature 214:597-598

20. Gilman AG 1970 A protein binding assay for adenosine $3^{\prime}: 5^{\prime}$-cyclic monophosphate. Proc Natl Acad Sci USA 67:305-312

21. Scatchard G 1949 The attraction of protein for small molecules and ions. Ann NY Acad Sci 51:660-672
22. Cheng Y, Prusoff WH 1973 Relationship between the inhibition constant $\left(K_{1}\right)$ and the concentration of inhibitor which causes 50 per cent inhibition $\left(I_{50}\right)$ of an enzymatic reaction. Biochem Pharmacol 22:3099-3108

23. Engel G 1981 Subclasses of beta-adrenoreceptors-a quantitative estimation of beta-1 and beta-2-adrenoreceptors in guinea pig and human lung. Postgrad Med J 57(suppl 1):77-83

24. Benovic JL, Stiles GL, Lefkowitz RJ, Caron MG 1983 Photoaffinity labelling of mammalian beta-adrenergic receptors: metal-dependent proteolysis explains apparent heterogeneity. Biochem Biophys Res Commun 110:504-511

25. Barnes PJ, Karliner JS, Dollery CT 1980 Human lung adrenoreceptors studied by radioligand binding. Clin Sci 58:457-461

26. Falkay G, Nemeth G, Kovacs L 1986 Binding properties of beta-adrenergic receptors in early human fetal lung Biochem Biophys Res Commun 135:816822

27. Kent RS, De Lean A, Lefkowitz RJ 1980 A quantitative analysis of betaadrenergic receptor interactions: resolution of high and low affinity states of the receptor by computer modeling of ligand binding date. Mol Pharmacol 17:14-23

28. Stiles GL, Caron MG, Lefkowitz RJ 1984 Beta-adrenergic receptors: biochemical mechanisms of physiologic regulation. Physiol Rev 64:661-743

29. Brown LAS, Longmore WJ 1981 Adrenergic and cholinergic regulation of lung surfactant secretion in the isolated perfused rat lung and in the alveolar type II cell in culture. J Biol Chem 256:66-72

30. Dobbs LG, Mason RJ 1979 Pulmonary alveolar type II cells isolated from rats Release of phosphatidylcholine in response to beta-adrenergic stimulation. J Clin Invest 63:378-387

31. Mettler NR, Gray ME, Schuffman S, LeQuire VS 1981 Beta-adrenergic induced synthesis and secretion of phosphatidylcholine by isolated pulmonary alveolar type II cells. Lab Invest 45:575-586

32. Rooney SA 1985 The surfactant system and lung phospholipid biochemistry. Am Rev Respir Dis 131:439-460

33. Cheng JB, Goldfien A, Ballard PL, Roberts JM 1980 Glucocorticoids increase pulmonary beta-adrenergic receptors in fetal rabbit. Endocrinology 107:1646-1648

34. Das DK, Ayromlooi J, Bandyopadhyay D, Bandyopadhyay S, Neogi A, Steinberg $\mathrm{H} 1984$ Potentiation of surfactant release in fetal lung by thyroid hormone action. J Appl Physiol 56:1621-1626

35. Maniscalco WB, Shapiro DL 1983 Effects of dexamethasone on beta-adrenergic receptors in fetal lung explants. Pediatr Res 17:274-277 